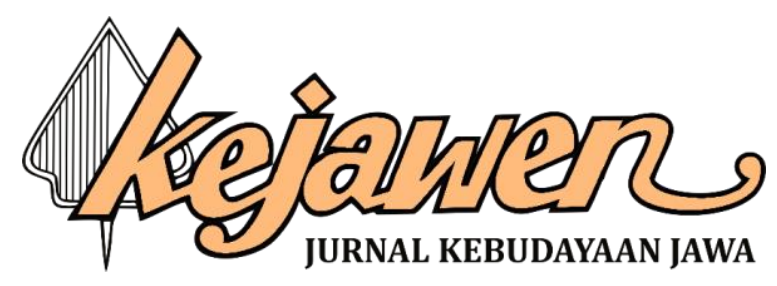

\title{
RELEVANSI TOKOH YUSUF DENGAN KARAKTER PEMIMPIN DEMOKRATIS: KAJIAN FILOLOGI SERAT YUSUF
}

\author{
Meinita Istantiani, Respati Retno Utami \\ Universitas Negeri Surabaya \\ meinita.18025@mhs.unesa.ac.id, respatiutami@unesa.ac.id
}

\begin{abstract}
Abstrak
Artikel dengan judul Relevansi Tokoh Yusuf dengan Karakter Pemimpin Demokratis: Kajian Filologi Serat Yusuf bertujuan untuk menggali lebih dalam sosok Nabi Yusuf dan relevansinya dengan karakter pemimpin demokratis. Karakter yang dimiliki Nabi Yusuf dapat dijadikan suri tauladan sosok pemimpin demokratis. Dilihat dari jenisnya, penelitian ini termasuk dalam penelitian filologi mengingat sumber utamanya yaitu Serat Yusuf dengan huruf Arab Pegon. Penelitian ini juga didukung oleh sumber literatur lain yang berfungsi untuk mendukung dan mempertajam penelitian. Metode pengumpulan data yang digunakan adalah metode filologi dan kepustakaan. Teori yang digunakan adalah teori strukturalisme genetik. Strukturalisme genetik merupakan teori yang mengaitkan karya sastra dengan fakta sosial serta pandangan dunia. Teknik analisis data dilakukan secara kualitatif deskriptif. Hasil penelitian menunjukkan bahwasanya tokoh Yusuf memiliki karakter yang selaras dengan karakter pemimpin demokratis. Karakter yang dimiliki oleh Nabi Yusuf diantaranya jujur, taat beragama, sabar, teguh, rela berkorban, pemaaf, berserah diri, dan adil. Apabila pemimpin generasi sekarang mampu meneladani dan menginternalisasi karakter Nabi Yusuf, maka akan tercipta sosok-sosok pemimpin demokratis di negeri ini.
\end{abstract}

Kata kunci: karakter, Yusuf, pemimpin demokratis

\section{YUSUF FIGURE RELEVANCE WITH CHARACTER DEMOCRATIC LEADERS: A STUDY OF THE PHILOSOPHY OF SERAT YUSUF}

\begin{abstract}
The article entitled The Relevance of Yusuf to the Character of a Democratic Leader: The Study of Yusuf's Fiber Philology aims to dig deeper into the figure of the Prophet Yusuf and its relevance to the character of a democratic leader. The characters possessed by the Prophet Yusuf can be used as role models for democratic leaders. Judging from its type, this research is included in philological research considering that its main source is Serat Yusuf with the Arabic alphabet Pegon. This research is also supported by other literature sources that serve to support and sharpen research. The data collection methods used are philology and literature methods. The theory used is the theory of genetic structuralism. Genetic structuralism is a theory that links literary works to social facts and world views. The data analysis technique was carried out in a qualitative descriptive manner. The results showed that the character Yusuf has a character that is in line with the character of a democratic leader. The characters possessed by the Prophet Yusuf include being honest, religious, patient, determined, willing to sacrifice, forgiving, surrendering, and just. If the leaders of the current generation are able to emulate and internalize the character of the Prophet Yusuf, then democratic leaders will be created in this country.
\end{abstract}

Keywords: character, Yusuf, democratic leader 


\section{PENDAHULUAN}

Dewasa ini banyak dijumpai kasus kemerosotan karakter seorang pemimpin. Seorang pemimpin yang harusnya menjadi panutan bagi orang yang dipimpinnya justru tidak mencerminkan karakter seorang pemimpin. Hal ini dibuktikan dari maraknya kasus-kasus yang menjerat para pemimpin. Diantaranya masih terjadi kasus korupsi, kesewenang-wenangan pemimpin, dan kekerasan oleh pemimpin/atasan kepada karyawannya. Berdasarkan data dari Indonesia Corruption Watch (ICW), total terdakwa kasus korupsi di Indonesia di tahun 2020 mencapai 1.298 orang. Dari data tersebut tercatat praktik korupsi dilakukan paling besar oleh Aparatur Sipil Negara (ASN) dengan 321 kasus, pihak swasta dengan 286 kasus, dan perangkat desa dengan 330 kasus. Total kerugian negara akibat tindak pidana korupsi mencapai 56,7 triliun. Uang pengganti yang kembali ke negara atas kerugian kasus korupsi tersebut hanya sebesar 1213\%, yakni sekitar 8,9 triliun saja. Selebihnya, uang negara tidak dapat kembali. Munculnya kasus demikian disebabkan karena pemimpin yang belum sepenuhnya memiliki jiwa demokratis. Pemimpin demokratis merupakan pemimpin yang mengedepankan kerja tim untuk mencapai tujuan bersama. Seorang pemimpin demokratis juga mampu menerima pendapat, kritik, dan saran dari karyawannya. Dalam proses pengambilan keputusan, pemimpin demokratis tidak bertindak secara otoriter, akan tetapi melibatkan karyawannya secara aktif. Pendapat ini didukung oleh Adi (2019:3) yang menyatakan bahwasanya gaya kepemimpinan yang baik adalah gaya kepemimpinan yang dapat memberikan pengarahan yang baik pada bawahannya.

Karakter pemimpin demokratis tidak hanya perlu dipahami, tetapi dalam kenyataannya harus diinternalisasi dalam kehidupan sehari-hari. Hal ini bertujuan untuk menekan potensi kasus yang muncul akibat perilaku pemimpin yang tidak demokratis. Dengan munculnya pemimpin yang berkarakter demokratis, maka akan tercipta integrasi yang kuat antara atasan dengan bawahan. Indikator untuk mengukur kedemokratisan seorang pemimpin juga dapat dilihat dari hubungan antara pimpinan dengan bawahan. Apabila terjalin komunikasi yang baik antara pemimpin dengan karawan, maka akan meningkatkan semangat kerja. Sebagaimana yang diungkapkan oleh Adi (2019:4) bahwasanya kepemimpinan yang baik dan tepat berguna untuk memunculkan kesadaran bagi karyawan mengenai pentingnya kerja yang optimal, disiplin, dan profesional.

Penelitian ini mengkorelasikan sosok Nabi Yusuf dengan karakter pemimpin demokratis. Nabi Yusuf merupakan sosok laki-laki berkarakter mulia. Sepanjang perjalanan Nabi Yusuf sejak masih kecil hingga diangkat menjadi seorang raja di Mesir dapat dijadikan suri tauladan bagi pemimpin generasi saat ini. Karakter yang dimiliki oleh Nabi Yusuf sudah ditunjukkan sejak masih belia. Atas dasar bimbingan orang tuanya yakni Nabi Ya'qub, Nabi Yusuf tumbuh menjadi seorang pemuda yang berakhlak. Sejak kecil Yusuf dikenal sebagai orang yang jujur dan taat beragama. Hal ini dapat ditunjukkan dari mimpi-mimpi beliau yang selalu diceritakan kepada ayahnya, Nabi Ya'qub. Dari mimpi Yusuf tersebut, Nabi Ya'qub menafsirkan bahwasanya Yusuf memiliki keistimewaan yang tidak dimiliki oleh saudaranya yang lain. Nabi Ya'qub percaya bahwasanya Nabi Yusuf akan mewarisi wahyu orang tuanya sebagai sosok khalifah di bumi. Fakta membuktikan, setelah menginjak dewasa Nabi Yusuf mendapatkan wahyu dari Tuhan dan diangkat menjadi raja yang bijaksana di kota Mesir.

Atas dasar keprihatinan peneliti terhadap karakter pemimpin generasi sekarang, peneliti membuka ruang baru dengan menelusuri relevansi tokoh Yusuf dengan karakter pemimpin demokratis. Peneliti memilih objek tokoh Yusuf dengan alasan Nabi Yusuf memiliki karakter yang selaras dengan karakter pemimpin demokratis. Di lain sisi, Nabi Yusuf juga pernah menjadi pemimpin di Mesir hingga mencapai puncak kejayaan. Dengan mengangkat tokoh Yusuf sebagai topik pembahasan, diharapkan mampu menambah wawasan mengenai karakteristik yang harus dimiliki oleh seorang pemimpin demokratis. Hal ini bertujuan untuk menyadarkan pemimpin dan calon pemimpin agar bahwasanya negeri ini mengharapkan sosok pemimpin yang demokratis agar tercipta keadaan yang kondusif. 
Permasalahan yang akan diangkat dalam penelitian ini adalah bagaimana gambaran tokoh Yusuf dalam Serat Yusuf dan bagaimana relevansinya dengan karakter seorang pemimpin demokratis. Melalui proses pengamatan, diketahui bahwasanya belum semua pemimpin memenuhi kriteria sebagai pemimpin demokratis. Dengan mengkaji tokoh Yusuf di dalam Serat Yusuf, peneliti mencermati karakter tokoh Yusuf selaras dengan karakter ideal pemimpin demokratis. Oleh karena itu, dalam penelitian ini akan mengulas mengenai gambaran tokoh Yusuf yang patut diteladani sebagai sosok pemimpin demokratis.

Sejalan dengan permasalahan yang akan dibahas, penelitian ini bertujuan untuk mengetahui gambaran tokoh Yusuf dan bagaimana relevansinya dengan karakter pemimpin demokratis. Sejatinya belum ada penelitian yang mengkorelasikan antara sosok Nabi Yusuf dengan karakter pemimpin demokratis. Penelitian yang pernah dilakukan sebelumnya hanya menggali karakter maupun kepemimpinan Nabi Yusuf yang diceritakan dalam Al-Qur'an. Kalaupun ada penelitian yang mengulas tentang kepemimpinan demokratis, tetapi belum dikorelasikan dengan karakter Nabi Yusuf. Oleh karena itu, penelitian ini menjadi khas karena membuka pemahaman baru yang belum pernah ditelusuri sebelumnya. Perlu kita ketahui, dalam sebuah komunitas, organisasi, maupun instansi tertentu pasti memerlukan sosok pemimpin yang demokratis.

Penelitian ini menggunakan teori strukturalisme genetik untuk mengkaji permasalahan yang ada di dalamnya. Goldmann dalam Faruk (2009:56) menyatakan bahwa teori strukturalisme genetik merupakan perwujudan sebuah struktur dari karya sastra. Cakupan pembahasan dalam strukturalisme genetik meliputi subjek kolektif, strukturasi, fakta kemanusiaan, pandangan dunia, serta adanya pemahaman yang tepat. Keterkaitan teori tersebut dengan penelitian adalah dalam penelitian ini peneliti mengkaji bagaimana fakta sosial dan pandangan dunia terkait kepemimpinan saat ini, utamanya terkait karakter yang dimiliki oleh pemimpin. Selain strukturalisme genetik, penelitian ini juga menggunakan teori filologi. Teori filologi ini digunakan untuk memahami maksud cerita yang ada dalam Serat Yusuf. Filologi merupakan bidang kajian ilmu yang objek penelitiannya meliputi naskah-naskah lama (Djamaris, 1977:20). Naskah-naskah lama yang dimaksud disini adalah naskah Jawa. Alur penelitian filologi meliputi penentuan naskah, inventarisasi naskah, deskripsi naskah, perbandingan naskah dan teks, suntingan teks, terjemahan teks, dan analisis isi (Oman, 2015:69).

Penelitian sebelumnya terkait sosok Nabi Yusuf maupun kepemimpinan Nabi Yusuf sudah ada. Tetapi rata-rata penelitian tersebut bersumber dari Al-Quran. Sedangkan penelitian yang mengulas tentang cerita Yusuf yang bersumber dari Serat Yusuf belum ada. Oleh karena itu, penelitian tentang relevansi tokoh Yusuf dengan karakter pemimpin demokratis belum ada. Penelitian terdahulu yang sudh dilakukan antara lain penelitian yang berjudul Kepemimpinan Pendidikan Nabi Yusuf oleh M. Zainul Arifin (2016), Nilai-Nilai Pendidikan Akhlak dalam Kisah Nabi Yusuf AS dan Implikasinya pada Pendidikan Akhlak di Sekolah oleh Elis Nur Hasanah (2019). Selain terbit di jurnal, penelitian terkait Nabi Yusuf juga pernah dijadikan sebagai objek skripsi yaitu skripsi dengan judul Kepemimpinan Nabi Yusuf dalam Al-Qur'an oleh Ahmad Zulkhoir Lubis (2015), Nilai-Nilai Pendidikan Karakter Bangsa dalam Kisah Nabi Yusuf A.S oleh Yesi Yusita Anggraini Putri (2018). Berkaca dari beberapa penelitian sebelumnya, penelitian ini merupakan penelitian yang baru dan mengaitkan dua variabel di dalamnya, yakni sosok Nabi Yusuf dan karakter pemimpin demokratis.

\section{METODE}

Jenis penelitian yang dilakukan oleh peneliti adalah penelitian kualitatif. Metode penelitian kualitatif adalah metode penelitian yang berlandaskan pada filsafat post positivisme, digunakan untuk meneliti pada kondisi objek yang alamiah, (sebagai lawannya eksperimen) dimana peneliti adalah sebagai instrumen kunci, pengambilan sampel sumber data dilakukan secara purposive dan snowball, teknik pengumpulan data dengan triangulasi (gabungan), analisis data bersifat induktif 
atau kualitatif, dan hasil penelitian ini lebih menekankan makna daripada generalisasi (Sugiyono, 2013:1). Sumber data yang digunakan dalam penelitian ini terbagi menjadi dua macam, yaitu sumber data primer dan sumber data sekunder. Sumber data primer diperoleh dari Serat Yusuf yang didapatkan dari Museum Mpu Tantular Sidoarjo dengan naskah bertuliskan Arab Pegon. Waktu pengambilan data primer dilaksanakan pada bulan Februari 2020 di Museum Mpu Tantular Sidoarjo. Sedangkan sumber data sekunder diperoleh dari sumber lain selain naskah asli Serat Yusuf. Sumber data sekunder yang digunakan antara lain mencari literatur dari jurnal yang membahas tentang gambaran tokoh Yusuf. Selain itu, peneliti juga mencari literatur yang membahas tentang karakteristik pemimpin demokratis. Waktu pengambilan data sekunder dilakukan oleh peneliti sekitar bulan November-Desember 2020 melalui pencarian di jurnal online. Dengan dukungan data sekunder, peneliti lebih terbuka untuk memaknai gambaran tokoh Yusuf dan mengetahui karakteristik pemimpin demokratis.

Teknik pengumpulan data pada penelitian ini menggunakan dua cara. Pengumpulan data yang pertama menggunakan teori filologi. Dengan menggunakan teori filologi, data primer diolah dengan prinsip filologi agar lebih mudah diteliti. Tahapan filologi yang dilakukan oleh peneliti yaitu inventarisasi naskah, deskripsi naskah, transliterasi, kritik teks, menerjemahkan teks, dan melaksanakan tahapan analisis teks Serat Yusuf. Dengan melakukan tahapan-tahapan filologi, didapatkan naskah terjemahan yang siap untuk diteliti. Pengumpulan data yang kedua yaitu dengan cara studi kepustakaan (Library Research). Peneliti mengumpulkan data-data lain yang bersifat mendukung penelitian ini. Data dikumpulkan dengan cara mencari sumber-sumber terkait topik yang bersifat untuk mendukung atau membandingkan. Peneliti juga mengumpulkan data melalui pencarian terhadap tulisan sebelumnya yang relevan dengan topik yang dibahas. Adapun pengambilan sampel dalam penelitian ini menggunakan purposive sampling, yaitu mencari data yang diperlukan sesuai dengan rumusan masalah. Sampel (cuplikan) yang diambil bersifat selektif, menyesuaikan dengan kebutuhan peneliti. Adapun triangulasi yang digunakan dalam penelitian ini adalah triangulasi teori, yaitu cara penelitian terhadap topik yang sama dengan menggunakan teori yang berbeda dalam proses analisis data.

Teknik analisis data diakukan secara kualitatif atau dikenal dengan analisis deskriptif kualitatif. Data yang telah terkumpul diuraikan secara deskriptif dengan cara mendeskripsikan fakta-fakta yang dilanjutkan dengan penguraian serta memberikan penjelasan yang cukup (Ratna, 2012:53). Keseluruhan data yang sudah dikumpulkan oleh peneliti selanjutnya dianalisis secara sistematis. Selanjutnya peneliti melakukan tindakan analisis isi. Analisis isi (content analiysis) merupakan teknik penelitian untuk membuat referensi-referensi yang dapat ditiru dan kesahihan data dengan memerhatikan konteksnya. Analisis isi berhubungan dengan komunikasi atau isi komunikasi (Bungin, 2011:163).

\section{HASIL DAN PEMBAHASAN}

Serat Yusuf yang dijadikan sumber primer dalam penelitian ini merupakan naskah berhuruf Arab Pegon dengan jumlah halaman sebanyak 161 halaman. Naskah ini memiliki ukuran spesifik dengan panjang $22 \mathrm{~cm}$, lebar $26 \mathrm{~cm}$, dan tebal $3 \mathrm{~cm}$. Serat Yusuf diperoleh dari hasil observasi di Museum Mpu Tantular Sidoarjo, Jawa Timur. Naskah ini memiliki nomor inventarisasi 07.208 M. Saat didapatkan, keadaan naskah ini masih baik dan dalam kondisi yang utuh, artinya tidak ada penggalan-penggalan naskah yang tercecer. Dikarenakan naskah ini beraksara Pegon, maka sering dijumpai kosakata berbahasa Arab di dalamnya. Ringkasan isi dari Serat Yusuf ini menceritakan perjalanan hidup Nabi Yusuf sejak masih kecil hingga beliau diangkat menjadi nabi. Dalam proses perjuangannya, Nabi Yusuf terdidik menjadi sosok yang berkarakter dan berakhlak mulia. Saat menginjak dewasa Nabi Yusuf mendapatkan sebuah kepercayaan yang terhormat, yakni diangkat menjadi seorang raja di Mesir. Dalam penelitian ini, akan diuraikan bagaimana karakter Nabi Yusuf serta relevansinya dengan pemimpin demokratis. Lebih jelasnya, hasil dan pembahasan dari penelitian diuraikan sebagai berikut. 


\section{Gambaran Tokoh Yusuf dalam Serat Yusuf}

Dalam Serat Yusuf, tokoh Yusuf digambarkan sebagai sosok laki-laki yang berkarakter dan memiliki keistimewaan. Karakter Yusuf ini dipaparkan secara tersurat maupun tersirat di dalam Serat Yusuf. Sifat yang dimiliki oleh Nabi Yusuf dapat diketahui dari proses dan perjuangan beliau sewaktu masih belia hingga beliau diangkat menjadi raja di negara Mesir. Dalam perjalanan hidupnya, Nabi Yusuf mendapatkan banyak rintangan kehidupan, baik dari keluarga maupun orang-orang di sekitarnya. Beberapa gambaran tokoh Yusuf yang dipaparkan dalam Serat Yusuf sebagai berikut.

Jujur

Nabi Yusuf dikenal sebagai orang yang jujur. Kejujuran yang dimiliki oleh Nabi Yusuf dapat diketahui dari upayanya untuk menceritakan mimpi-mimpinya kepada sang ayah, Nabi Ya'qub. Nabi Yusuf tidak hanya bermimpi sekali saja, tetapi sudah berulang kali. Setiap mimpi yang dialami oleh Nabi Yusuf selalu diceritakan kepada Nabi Ya'qub. Dari peristiwa ini terlihat bahwasanya karakter jujur Nabi Yusuf sudah dimiliki sejak kecil. Hal ini dapat dibuktikan melalui kutipan pada bait ke 25 dan 26 Serat Yusuf di bawah ini.

\section{"Angipi sira ningali/ srengenge kalawan wulan/lintang sawêlas ruwahiya/ samya asujuding sira/ dina malêm jumat/ tatkala angipi niku/ yusup murub tiningalan//" \\ "Atangi pajar niki/ bapak angipi kawula/ srengenge lan wulan rêku/ kalawan lintang sêwêlas/ nabi yaqub anabda/ menenga anak ingsun/ abarah umung ipi sira//"}

Terjemahan:

"Bermimpi melihat/ matahari dan bulan/ bintang sebelas ruwah/ sama-sama bersujud padamu/ hari malam jumat/ ketika bermimpi itu/ yusup terlihat bercahaya//"'

"Bangun di pagi hari ini/ bapak bermimpi/ matahari dan bulan /dengan bintang sebelas/ nabi yaqub bersabda/ diamlah anak saya/ menghilang keramaian mimpi anda//"

Kutipan di atas membuktikan bahwasanya Nabi Yusuf bermimpi pada malam Jumat. Beliau bermimpi melihat matahari, bulan, serta sebelas bintang yang bersujud kepadanya. Pada saat memimpikan hal tersebut, Nabi Yusuf terlihat bercahaya. Setelah memimpikan hal tersebut, Nabi Yusuf bercerita kepada sang ayah, Nabi Ya'qub. Mendengar cerita tentang mimpi Yusuf, Nabi Ya'qub menyadari jika Nabi Yusuf memiliki keistimewaan dibandingkan dengan saudarasaudara yang lainnya. Dengan bermimpi melihat matahari, bulan, dan sebelas bintang yang bersujud kepadanya, maka Nabi Yusuf akan menjadi seseorang yang dipatuhi. Sejak saat itulah, Nabi Ya'qub menyadari bahwasanya suatu saat nanti Nabi Yusuf akan mewarisi kenabiannya dan menjadi seorang pemimpin yang dipatuhi oleh umatnya.

Karakter jujur sebagaimana yang dimiliki oleh Nabi Yusuf perlu diterapkan dalam kehidupan sehari-hari. Jujur mencerminkan salah satu sifat Nabi dan Rasul, bahkan menjadi sifat wajib yang dimiliki oleh nabi dan rasul (Amin, 2017:108). Jujur merupakan perwujudan dari tingkah laku apa adanya, sesuai dengan kenyataan, tidak ditutup-tutupi, serta tidak berbohong. Pendapat ini didukung oleh Muchlas Samani dan Hariyanto yang mengatakan bahwasanya jujur adalah menyatakan apa adanya, terbuka, konsisten antara apa yang dikatakan dengan yang dilakukan, berani karena benar, dapat dipercaya, dan tidak curang (Samani, 2013:51). Pendapat lain juga menyebutkan bahwasanya jujur adalah sikap dan perilaku yang tidak berbohong dan berbuat curang, berkata apa adanya, serta berani mengakui kesalahan yang dilakukan. Definisi jujur juga dapat diartikan berkata dan memberikan informasi sesuai dengan fakta sebenarnya (Nurul dalam Amin, 2017:110). Sifat jujur dapat dikategorikan menjadi jujur dalam berbicara dan jujur dalam bertindak. Orang yang memiliki sifat jujur akan berbicara sesuai dengan fakta, tidak 
ada bumbu-bumbu kebohongan di dalamnya. Dari sifat jujur inilah, akan muncul kepercayaan orang lain terhadap kita. Orang yang sudah terbiasa bersikap jujur, akan banyak dipercaya oleh orang lain. Sebaliknya, orang yang bersifat dusta akan dijauhi oleh orang lain. Kejujuran atau integritas merupakan modal kehidupan yang sangat penting di era sekarang. Sekarang ini, kejujuran mahal harganya. Tidak jarang orang yang bersikap jujur justru kalah dengan orang yang bertindak dusta. Akan tetapi, perlu diketahui bahwasanya sikap jujur pasti akan membawa kebaikan pada akhirnya. Dengan membiasakan bersikap jujur, maka hati akan terasa tenang. Jujur akan membawa seseorang ke dalam sebuah kedamaian.

\section{Taat Beragama}

Sejak belia, Nabi Yusuf sudah memilki sikap taat beragama. Beliau senantiasa menyembah Tuhan dan mengikuti ajaran islam yang dibawa oleh ayahnya, Nabi Ya'qub. Sikap taat beragama yang dimiliki oleh Nabi Yusuf tercermin dalam kehidupannya sehari-hari. Sebagaimana yang terdapat dalam bait 1124-1126 Serat Yusuf.

Wontên andikaning widi/ ing bagindha rasul ika/ sing angangkat tangan karo/ ananêdha ing yang suksêma/ yèn sira tan pasunga/ ing panêdha nira iku/ awirang sira yang suksêmall

Katingalé qabul nikil dongané wong amanêdhal tatkalané sahur siral sujud sawêngi pisan/ lan sêdhêng puwasa niku/ lawan tatkala dêrês udan/l

Muwa ta malih mangkiki/ tatkala malêm jumangat/ mewing rahina niki mangku/ lan sawusé waktu ngashar/ Ing ari aya kalêya/ karana rahmat yang agung/akêwi tumurun ing rika/l

Sing sapa sujud ing mangkél kang liyan saking yang suksêma/ wong iku pasthi narêku/ satuhuné dadi kopar/ sing asujud mring lêyan/ mangkana pinanggihipun/ sing angrungu wistaraal/

Terjemahan:

Dalam sabdanya Tuhan/ baginda rasul ini/ mengangkat kedua tangan/ meminta kepada Tuhan/ jika kamu tidak diberi/ permintaanmu itu/ malulah kamu kepada sang Tuhan//

Diijabahnya/ doanya orang yang meminta/ ketika sahurmu/ sujud semalam/ dan ketika puasa/ serta ketika hujan deras//

Dan lagi nanti/ ketika malam Jumat/ juga siang itu/ dan setelah waktu ashar/ di hari itu/ karena rahmat sang Tuhan/ banyak turun ketika itu//

Barang siapa bersujud/ selain kepada Tuhan/ orang itu pasti masuk neraka/ sesungguhnya terbakar/ yang bersujud kepada yang lain/ seperti itu pendapatnya/ yang mendengar ceritanya//

Kutipan di atas menggambarkan bahwasanya Nabi Yusuf merupakan sosok laki-laki yang taat beribadah. Nabi Yusuf selalu berdoa mengangkat kedua tangan untuk menyembah dan memohon kepada Tuhan Yang Maha Esa. Apabila kita sudah meminta kepada Tuhan tetapi permintaan tersebut belum dikabulkan, maka hendaknya malu kepada Tuhan. Dalam bait 1125 Serat Yusufjuga dijelaskan bahwa waktu mustajab bagi orang yang meminta adalah ketika sahur, sujud semalam (sholat malam), ketika sedang berpuasa, dan ketika sedang terjadi hujan deras. Waktu-waktu tersebut merupakan waktu mustajab dan dapat digunakan sebagai kesempatan untuk memohon kepada Tuhan. Selain waktu tersebut, juga terdapat waktu mustajab yang lain sebagaiman dijelaskan dalam bait ke-1126 Serat Yusuf. Waktu mustajab yang lain yaitu ketika malam Jumat hingga Jumat sore (setelah waktu ashar). Sebagai umat muslim tentunya sayang jika melewatkan waktu-waktu tersebut. Karena rahmat Tuhan banyak yang turun pada saat itu. 
Taat beragama merupakan wujud bakti seorang hamba kepada Tuhannya. Taat dapat diartikan patuh atau tunduk ketika mendapatkan perintah, serta menghindari hal-hal yang dilarang/tidak diperbolehkan (Anwar, 2020:8). Agama adalah proses hubungan manusia yang dirasakan dengan sesuatu yang diyakininya, bahwa seseuatu tersebut memiliki tingkatan lebih tinggi daripada manusia (Darajat, 1970:24). dari penjelasan di atas dapat disimpukan bahwa taat beragama merupakan sifat patuh dan tunduk terhadap ajaran agama, serta menjauhi hal-hal yang dilarang dalam agama. Dengan kata lain taat beragama adalah amar ma'ruf nahi munkar. Setiap manusia yang beragama haruslah memiliki sifat taat beragama. Selaras dengan kisah Nabi Yusuf, taat beragama yang dijelaskan adalah melaksanakan ibadah/sholat lima waktu bagi kaum muslim. Sholat merupakan tiang agama. Barang siapa menegakkan sholat berarti ia menegakkan agama. Sebaliknya, barang siapa meninggalkan sholat, berarti ia merobohkan tiang agama. Begitu pentingnya ketaatan beragama di dalam agama Islam. Orang yang memiliki sifat taat beragama akan menjadikan orang tersebut sholih atau sholihah. Dengan selalu mendekatkan diri kepada sang pencipta, maka kita akan senantiasa ingat bahwasanya Allah menciptakan manusia di dunia ini untuk beribadah kepada-Nya. Oleh karena itu, wajib hukumnya bagi setiap muslim untuk selalu menjalankan sholat lima waktu dalam keadaan dan kondisi apa pun selagi ia masih hidup.

\section{Sabar}

Kesabaran Nabi Yusuf teruji ketika beliau dibuang oleh saudara-saudaranya sendiri ke dalam sumur. Motif yang dilakukan oleh saudaranya adalah karena mereka merasa iri dengan keistimewaan yang dimiliki oleh Nabi Yusuf. Mereka mengetahui keistimewaan Nabi Yusuf dari cerita mimpi-mimpinya yang disampaikan kepada Nabi Ya'qub. Atas dasar itulah, saudara Nabi Yusuf merencanakan strategi untuk membuang Nabi Yusuf. Nabi Yusuf yang belum sadar jika akan dibuang, menurut saja saat bajunya dilepas oleh saudaranya. Saudaranya kemudian memasukkan Nabi Yusuf ke dalam sumur. Tidak kehabisan akal, saudara-saudaranya melumuri baju Nabi Yusuf dengan darah dan membawa pakaian tersebut ke rumah untuk disampaikan kepada ayahnya bahwasanya Nabi Yusuf sudah meninggal dimakan anjing hutan. Peristiwa ini dapat dibuktikan melalui kutipan dalam naskah pada bait ke-80 Serat Yusuf.

Tan kocapa yusup niki/ kocapa kang para sanak/ pada ararasan mangku/ riyênira pajaraing sira ramanira/ yên sampun baginda yusup/ pinangane asu alas/ karane tan kapidua/ kalambi yusup mangku/ ingurapan raina minda/ pinaka cina nira/ yên sampun baginda yusup/ pinangane asu alas//

Eh putêra ya'qub sadaya/ angalap sira ing uni/ sanguné yusup tah mangku/denira panganakên aglis/ mêring asu niriki/ lan amutakên iku/ banyu ing jêro wadhah/ sanguné yusup ing uni/ dèn silêm banyu den tapuk dènirall

Yata sami mantuk tiki/ prapting omah paptu isak/ nubêya marêk kabeh rêku/ mara ring ramanira/ pada anangis sira/ apajar yên nabi yusup/ pinangane asu alas//

Terjemahan:

Tidak berbicara yusup ini/ berbicara para saudara/ sama membicarakan seperti itu/ didahului ayahnya/ ketika sudah baginda yusup/ dimakan anjing hutan/ karena tidak kapidua/ baju yusup itu/ ingurapan ketika siang/ pinaka cina itu/ ketika sudah baginda yusup/ dimakan anjing hutan//

Eh putra ya'qub semua/ perhatikan perkataanmu/ sakunya yusup nanti/ dimakankan segera/ kepada anjing/ dan ditenggelamkan/ dalam sebuah wadah air/ sakunya yusup/ ditenggelamkan ke dalam air//

Sama-sama pulang / sampai rumah waktu isyak/ nubeya selesai semua reku/ membilangi kepada bapaknya/ sama-sama menangis/ pagi hari ketika nabi yusup/ makanannya anjing huan// 
Berdasarkan kutipan di atas, diceritakan bahwasanya saudara-saudara Nabi Yusuf mengatakan jika Nabi Yusuf dimakan anjing hutan. Hal tersebut disampaikan kepada sang ayah, Nabi Ya'qub. Nabi Ya'qub seketika sedih mendengar kabar itu. Ditambah lagi, beliau juga melihat bekas baju yang dikenakan Nabi Yusuf sudah berlumuran darah. Saat itu, Nabi Ya'qub sangat sedih hingga setiap hari menangisi Yusuf.

Sementara pada situasi lain, Nabi Yusuf tetap bersabar berada dalam sumur yang dalam. Dalam hatinya, beliau tetap mengaharapkan kekuasaan Tuhan. Beliau berharap ada orang yang mau mengambil air di dalam sumur tersebut dan kemudian membantunya untuk keluar. Dengan penuh kesabaran dan harap, Nabi Yusuf menunggu berhari-hari di dalam sumur.

Sikap sabar dapat diartikan sebagai sikap bertahan dengan ikhlas. Sabar bukan berarti menujukkan kelemahan seseorang, tetapi sabar merupakan perwujudan dari kebijaksanaan. Dengan mengembangkan sikap sabar dalam situasi apa pun, termasuk dalam situasi terjepit, maka Allah akan memberikan pertolongan. Perintah untuk bersabar juga dijelaskan dalam Al-Qur'an pada surah Al-Baqarah ayat 155 yang artinya:

"Dan sesungguhnya akan kami berikan cobaan kepadamu, dengan sedikit ketakutan, kelaparan, kekurangan harta, jiwa dan buah-buahan. Dan berikanlah berita gembira bagi orang-orang yang sabar" (Q.S. Al-Baqarah: 155).

Demikianlah perintah Allah SWT menyuruh manusia untuk bersikap sabar dalam kondisi apa pun. Meskipun merasa takut, lapar, maupun kekurangan harta manusia tetap diperintahkan untuk berabar. Sebab dalam perjalanan hidup manusia ini tidak terlepas dari yang namanya cobaan. Sabar akan menjadikan seseorang menjadi kuat dan berbesar hati. Orang yang sabar akan mampu menerima segala cobaan dan musibah. Orang yang sabar rela menerima kenyataan pahit, sedangkan orang yang tidak sabar akan protes dan gelisah dengan nasibnya yang kurang baik (AlGhazali, 2013:9). Oleh karena itulah, sikap sabar perlu dibina sejak dini agar tercipta karakter orang-orang kuat dan tahan banting.

Sama halnya dengan sikap sabar yang dimiliki oleh Nabi Yusuf. Nabi Yusuf tetap bersabar ketika dimasukkan ke dalam sumur hingga berhari-hari. Atas kuasa Allah, akhirnya ada musafir yang menolongnya. Kesabaran yang dibina oleh seseorang akan mendatangkan manfaat dan keberkahan bagi orang yang melakukannya. Dengan bersabar, manusia tidak akan mudah putus asa ketika menghadapi situasi yang sulit. Mereka akan terus berusaha dan berdoa agar diberikan jalan terbaik. Sebagaimana firman Allah SWT bahwasanya Allah tidak akan menguji seseorang diluar batas kemampuannya. Dalam kesabaran, terkandung kebaikan di dalamnya. Kebaikan yang diperoleh bagi orang yang sabar adalah kebaikan dunia dan akhirat. Orang sabar akan selamat dan sukses dalam mengarungi perjalanan hidup.

Teguh

Selain memiliki sifat tersebut di atas, Nabi Yusuf juga dikenal sebagai seseorang yang memiliki sifat teguh. Keteguhan hati Nabi Yusuf dapat tercermin ketika beliau digoda oleh majikannya, Zulaikha. Meskipun sudah digoda dengan segala cara, Nabi Yusuf tetap teguh pendiriannya agar tidak mudah hanyut dalam jurang kenistaan. Zulaikha yang sudah terpaut cintanya kepada Yusuf memaksa Yusuf untuk bermain api dengannya. Saat Nabi Yusuf ingin menjauh, Zulaikha malah menarik baju Nabi Yusuf sehingga pada bagian belakang ada yang sobek. Hal ini dijelaskan dalam Serat Yusuf bait 477-479 berikut ini.

Sira wus kasulap muwal ing luh makhpud lamun nabi yang widi/ nurana awirang siriku/ ing yang sukma wisisa/ yata ilang tarêsna nira nabi Yusup/ aglis tumurun tasira/ saking pagulingan niki// 
Tinututan dèni radêyan cinandhak kalambini riki sêbit/ kêdhêngi mêdal siriku/Nabi Yusup kacaryan/dènira sang nata nabi Yusup iku/mapan wahu aluwêran/tinangkil satingal niki//

Sang putêri mangké wêruh sira/ yen sang nata angawêruhi siriki/ angruhoni sira atur/ sang pêrabu punapa/ wawalêsi ing wong dura cariku/ ing jêrone kedhaton tuan/ iriki winarangka iki//

Terjemahan:

Dia sudah tidak bisa kelihatan jelas/ di luh Makhfud jika nabi hyang widi/ cahaya yang ada malu terlihat/ di hyang sukma/ lalu hilang rasa cinta nabi Yusuf/ dia cepat turun/ dari tempat tidur itu//

Memegang pakaian sobek/ keluar dari tetiduran itu/ Nabi Yusuf senang/ oleh sang raja nabi Yusuf itu/ memilih baju dililitkan/ terlihat duduk dihadap ini//

Sang putri nanti tahu kamu/ jika sang raja mengetahui siriki/ mendahului kamu berucap/ apa sang prabu/ pembalasan pada orang jauh mencariku/ di dalam kedaton tuan/ disini penjara ini//

Berdasarkan kutipan di atas, Nabi Yusuf digambarkan sebagai sosok laki-laki yang memiliki keteguhan hati. Nabi Yusuf tidak mudah terpengaruh dengan tipu daya duniawi. Termasuk tipu daya Zulaikha yang dibutakan oleh cintanya kepada Nabi Yusuf. Saat raja keluar, Zulaikha menggoda Nabi Yusuf dengan cara mengajak ke dalam kamar. Sebelum masuk ke dalam jurang kenistaan lebih jauh, Nabi Yusuf segera melarikan diri keluar dari kamar. Namun, Zulaikha tidak menyerah begitu saja. Ia dengan segera menarik baju Yusuf hingga terdapat sobekan di bagian belakang. Nabi Yusuf segera lari dan keluar. Bersamaan dengan itu, raja tibatiba datang. Zulaikha yang tidak terima dengan Yusuf, kemudian mengancam Yusuf. Apabila Nabi Yusuf menceritakan kejadian ini kepada sang prabu, maka Zulaikha akan membalas Yusuf dengan cara memasukkannya ke dalam penjara.

Teguh merupakan sikap seseorang yang tahan terhadap godaan dan rintangan. Orang yang memiliki sifat teguh akan sulit dihancurkan oleh orang lain. Keteguhan hati menunjukkan komitmen diri yang dimiliki oleh seseorang. Keteguhan seseorang dapat diuji ketika orang tersebut mendapati sebuah godaan atau rintangan. Apabila orang tersebut tidak terkecoh dengan godaan tersebut, maka orang tersebut memang teguh seutuhnya. Akan tetapi, apabila masih terdapat keraguan, berarti keteguhan yang dimilikinya masih dipertanyakan. Sama halnya dengan keteguhan Nabi Yusuf untuk bersikukuh menolak ajakan Zulaikha. Nabi Yusuf benar-benar tidak tergoda dengan segala upaya yang dilakukan Zulaikha. Sikap seperti itulah yang dapat dijadikan teladan agar dalam menjalani kehidupan kita tidak mudah dihancurkan oleh orang lain hanya karena kita tidak memiliki keteguhan hati. Dengan memiliki sifat teguh, seseorang akan menjadi pribadi yang kuat.

\section{Rela Berkorban}

Setelah digoda oleh Zulaikha, Nabi Yusuf tidak menceritakan apa pun kepada raja. Akan tetapi, raja mencoba mencari kebenaran dengan cara menanyakan hal tersebut kepada orang yang dipercayainya. Orang kepercayaan Nabi Yusuf mengatakan apabila baju Yusuf di bagian depan berarti memang Nabi Yusuf yang bersalah. Namun apabila yang sobek adalah di bagian belakang, maka yang salah adalah istri raja, Zulaikha. Dan kenyataan membuktikan bahwasanya baju Nabi Yusuf sobek di bagian belakang. Hal tersebut membuktikan bahwasanya yang salah adalah Zulaikha.

Karena raja ingin memisahkan Nabi Yusuf dengan Zulaikha, maka raja memutuskan untuk memasukkan Nabi Yusuf ke dalam penjara. Nabi Yusuf tidak menanggapi hal ini sebagai sebuah penderitaan, akan tetapi sebagai wujud pengorbanan. Sebab Nabi Yusuf sadar bahwasanya beliau tidak pernah menggoda Zulaikha. Dengan dipenjarakan, Nabi Yusuf justru 
bersyukur karena dijauhkan dari segala tipu daya. Hal ini juga dapat dilihat dalam kutipan pada bait 510 Serat Yusuf berikut ini.

Ature mantri sang nata/ pênên sih pukulun malih/ warangka nêndi sang katong/ pangasêrirapanel ing nabi yusup niki/ karana matur kaiku/ panjaranên sang katong/ yata wontên kang kawarni/ sing kocapa jêro surat yusup jêrone quran// Terjemahan:

Kata mentri sang raja/ dipenjarakan dimana raja/ pada nabi Yusuf ini/ karena berkata seperti itu/ raja memenjarakan/ itu ada yang terucap/ yang terucap di dalam surat Yusuf dalam Al-Quran//

Berdasarkan kutipan di atas, diketahui bahwasanya menteri diperintah oleh raja untuk memenjarakan Nabi Yusuf. Hal ini juga diterangkan di dalam Al-Qur'an di dalam surat Yusuf. Melihat keadaan seperti ini, nabi Yusuf hanya pasrah. Beliau tidak memberontak untuk menolak dimasukkan ke dalam penjara. Nabi Yusuf menerima dengan ikhlas perlakuan sang raja kepadanya. Barangkali ini merupakan jalan yang dipilihkan Tuhan kepada Nabi Yusuf. Maka dari itu, Nabi Yusuf bersedia apabila dimasukkan ke dalam penjara sehingga dia terbebas dari hasutan Zulaikha.

Rela berkorban merupakan sikap seseorang yang ikhlas untuk mengorbankan sesuatu yang dimilikinya demi kebaikan. Rela berkorban juga menjadi cerminan kesungguhan hati seseorang. Demikian pula yang dilakukan oleh Nabi Yusuf. Nabi Yusuf rela mengorbankan dirinya masuk ke dalam penjara atas tuduhan menggoda Zulaikha. Menghadapi situasi demikian tidak membuat Nabi Yusuf marah meledak-ledak, tapi beliau ikhlas menjalani hukuman atas kesalahan yang tidak diperbuat. Nabi Yusuf selalu percaya jika hal ini sudah digariskan oleh Allah SWT. Beliau tinggal menjalaninya dengan ikhlas. Sikap rela berkorban seperti demikian perlu dikembangkan dalam kehidupan sehari-hari. Wujud rela berkorban dapat dimulai dari lingkungan terkecil yaitu keluarga. Dengan adanya binaan yang kuat, maka sikap rela berkorban akan mudah dimiliki oleh seseorang. Sejatinya, sikap rela berkorban memiliki kebermanfaatan yang besar. Rela berkorban akan mendidik jiwa seseorang untuk lebih semangat memperjuangkan sesuatu.

\section{Pemaaf}

Sebagai seseorang yang pernah mengalami kejadian pahit yang dilakukan oleh saudarasaudaranya, Nabi Yusuf tidak dendam kepada saudara-saudaranya tersebut. Ketika Nabi Yusuf diangkat menjadi raja, dirinya tidak serta merta membenci saudaranya. Ketika ada saudaranya yang pergi ke negara Mesir untuk mengambil gandum sebagai makanan pokok, saudaranya tidak mengerti jika yang menjadi raja di negara Mesir adalah putra Ya'qub, yaitu Nabi Yusuf. Dengan merancang strategi, Nabi Yusuf ingin bertemu dengan Bunyamin dan ayahnya, Nabi Ya'qub.

Berita itu disampaikan oleh saudara Nabi Yusuf kepada ayahnya setelah pulang ke rumah. Maka dari itu ketika hendak pergi ke negara Mesir, saudara Nabi Yusuf membawa ayahnya pergi kesana. Setibanya di Mesir Nabi Yusuf mengumumkan bahwasanya dirinya adalah Yusuf, putra Ya'qub. Seketika itu, Nabi Ya'qub meminta maaf atas semua yang sudah terjadi kepada Nabi Yusuf. Hal ini tercermin dalam kutipan berikut ini.

Satuhune ambah iki/ wus angapura ambah rama/ sadudune kabeh ringing/ yata nabi yusup mujar/ eh bapak saksenana/ eh bapak saksenana/ lan malikat ngung ngapural/

Terjemahan:

Sesungguhnya aku ini/ sudah memaafkan Bapak/ bukankah semua ringing/ kemudian nabi Yusuf berkata/ eh bapak saksikanlah/ saksikanlah sang Tuhan/ dan malaikat memaafkan// 
Berdasarkan kutipan di atas, tergambar dengan jelas bahwasanya Nabi Yusuf merupakan sosok orang pemaaf. Nabi Yusuf tidak dendam kepada ayah dan saudara-saudaranya meskipun sudah didzolimi. Beliau sudah berbesar hati untuk memaafkan kejahatan yang sudah diperbuat kepadanya di masa dahulu. Nabi Yusuf juga menggambarkan bahwasanya tidak hanya beliau saka yang memaafkan, akan tetapi Tuhan dan malaikat juga turut serta membuka pintu maaf. Hal itulah yang membuat Nabi Ya'qub merasa lega.

Pemaaf merupakan sikap berbesar hati untuk mengampuni kesalahan orang lain. Memaafkan orang lain merupakan suatu perbuatan yang terpuji. Lawan dari pemaaf adalah pemarah dan pendendam (Wahyuningtyas, 2017:1055). Memaafkan kesalahan orang lain berarti memuka jalan untuk menghapus penyakit hati yang masih tersisa dari dalam diri. Dengan memaafkan orang lain, maka dalam menjalani proses kehidupan ini akan tenang tanpa ada tanggungan. Hal mendasar yang perlu dipahami, bahwasanya setiap manusia pasti pernah melakukan kesalahan. Oleh karena itu, sebaiknya kita membukakan pintu maaf lebar-lebar bagi orang lain. Termasuk memaafkan kesalahan yang diperbuat oleh anggota keluarga. Sikap memaafkan juga sudah dijelaskan dalam Al-Qur'an surah Al-Imran ayat 132 yang artinya: "Dan orang yang menahan amarahnya dan memaafkan orang lain, Allah mencintai orang yang berbuat kebajikan". (QS Al-Imran:132).

Arti ayat tersebut menerangkan bahwasanya menahan amarah dan memaafkan orang lain merupakan suatu kebajikan. Allah SWT mencintai orang-orang yang berbuat kebajikan. Oleh karena itu, sikap memaafkan hendaknya dijadikan sebagai modal dan mental tangguh dalam menjalani kehidupan. Seperti yang terdapat dalam cerita Yusuf dimana Nabi Yusuf seringkali didzolimi dan dijahati oleh saudaranya, tetapi hal tersebut tidak membuat Nabi Yusuf dendam kepada mereka. Tanpa meminta maaf terlebih dahulu, jauh di dalam lubuk hati Nabi Yusuf sudah memaafkan kesalahan saudara-saudaranya. Nabi Yusuf juga bersedia membantu kebutuhan keluarganya yang pada saat itu sedang dilanda kekeringan di berbagai daerah. Pada dasarnya, tidak ada penyesalan bagi orang yang mau memaafkan kesalahan orang lain dari hati.

\section{Berserah Diri}

Sebagai seorang muslim, Nabi Yusuf senantiasa bersifat tawakal atau berserah diri. Ketika Nabi Yusuf dalam keadaan apa pun, beliau tidak lupa untuk selalu berserah diri kepada Tuhan Yang Maha Esa. Sikap tawakal ini juga sebagai pencerminan bahwasanya segala sesuatu tetap ada di tangan Tuhan. Manusia hanya bisa mengupayakan, sedangkan masalah hasil yang akan diterima dipasrahkan kepada Tuhan. Sikap berserah diri Nabi Yusuf tergambar dalam kutipan di bawah ini.

Kang minaka bukti nira/ puji maring sangyêng wisisa malih/ dikir minaka inumipun/ Anakin sri narendra/ punapa tah karyêni malih puniku/ baginda yusup lingira/ kinin rumaksa ingkami//

Terjemahan:

Sebagai bukti anda/ berdoa kepada sang yêng wisisa lagi/ berdzikir sebagai minumannya/ anaknya sri narendra/ apakah karyênya berubah seperi itu/ baginda yusup linggira/ kinin menjaga pada kami//

Dari kutipan di atas, diketahui bahwasanya Nabi Yusuf selalu melantunkan doa dan dzikir. Bagi Nabi Yusuf, berdzikir diumpamakan sebagai sebuah minuman. Maka dari itu, bisa ditafsirkan apabila kita tidak minum maka kita akan kehausan dan tidak bertenaga. Hal inilah yang tersirat dalam kutipan serat ini. Doa yang dilantunkan oleh Nabi Yusuf juga mencerminkan bahwasanya Nabi Yusuf adalah sosok pemimpin yang selalu berserah diri kepada Tuhan.

Berserah diri merupakan sikap memasrahkan hasil atau keputusan kepada Tuhan. Pendapat lain menambahkan bahwasanya tawakal adalah menyerahkan keputusan segala perkara, ikhtiar, dan usaha kepada Tuhan semesta alam (Hamka, 2013:232). Setelah manusia berupaya 
semaksimal mungkin, untuk mengimbangi upaya tersebut diperlukan sikap berserah diri (tawakal). Tawakal akan membuat hati seseorang lebih tenang dan tidak gelisah dengan kemungkinan apa saja yang akan terjadi ke depannya. Hal tersebut dikarenakan kita sudah percaya bahwasanya keputusan yang nantinya didapat merupakan keputusan terbaik dengan segala pertimbangannya. Dengan menerapkan sikap tawakkal dalam kehidupan sehari-hari, tidak akan ada rasa kecewa atas usaha yang telah dilakukan. Sebab kewajiban manusia memanglah berikhtiar (usaha). Usaha yang dilakukan pasti akan mencerminkan hasil yang diperoleh seseorang. Tawakal menjadi sebuah sikap yang diperintahkan oleh agama, terlebih dalam agama Islam. Allah SWT berfirman dalam Al-Qur'an surah At-Thalaq ayat 3 yang artinya: "Dan barangsiapa yang bertawakal kepada Allah, niscaya Dia-lah yang menjadi penjaminnya" (QS. AtThalaq [65]:3).

Arti ayat tersebut menjelaskan bahwasanya orang yang bersikap tawakal memiliki keistimewaan tersendiri di mata Allah. Dengan menyerahkan segala keputusan kepada Allah, maka Allah sendiri yang akan menjadi penjaminnya. Setiap keputusan yang datangnya dari Allah pasti selalu baik dan sesuai dengan kebutuhan hambanya. Oleh sebab itu, tidak perlu ragu untuk memasrahkan segala kehidupan kita kepada Allah SWT. Tuhan maha mengetahui apa yang terbaik bagi hambanya.

Adil

Nabi Yusuf digambarkan sebagai sosok pemimpin yang menegakkan keadilan. Keadilan yang ditegakkan oleh Nabi Yusuf dapat dirasakan oleh seluruh umat, terutama bagi warga Mesir. Nabi Yusuf mampu menjadi raja yang adil dan bijaksana dalam memimpin rakyatnya. Keadilan Nabi Yusuf ini juga diutarakan oleh warga Mesir. Hal ini tercermin dalam kutipan Serat Yusuf berikut ini.

Sakêwihe kang wong nyangking sira kawula/ sun dadikên kabike/ ngawula ing siral panggunggunge yang sukma/dhatêng nabi yusup niki/dadi narendra/adil ing bumi mêshir/l

Babune mangkiya tatanêya/ yusup mangke anèng êndi/ pun basyir angling mangke alon/ angadêk raja ing mêshir/ anata gama lêwi/ngadil palamarta tuhu/nêgu ing pangubaya/ balaba amakinaki/nora nana ratu ing donya mangkana/l

Terjemahan:

Kebanyakan orang yang membawamu hamba/ kujadikan semuanya/ menyembah padamu/ pada nabi Yusuf ini/ jadi raja/ adil di bumi mesir//

Pembantunya sedang menata/ yusup ada dimana/ basyir berkata dengan pelan/ berdiri menjadi raja di Mesir/ menata agama/ nyata adil dan berbelas kasih/ menepati janji/ tidak ada ratu di dunia seperti itu//

Berdasarkan kutipan di atas, diceritakan bahwasanya Nabi Yusuf berhasil menegakkan keadilan di negara Mesir. Hal ini dapat diketahui dari kepemimpinan Nabi Yusuf yang selalu menata agama, adil, berbelas kasih kepada orang lain, serta menepati janji. Dalam kutipan ini juga dijelaskan bahwasanya tidak ada ratu di dunia yang seperti Nabi Yusuf. Hal ini dapat dijadikan ciri khusus bahwasanya kepemimpinan di tangan Nabi Yusuf benar-benar berhasil dan mencapai pada masa kejayaan.

Adil dapat diartikan dengan sikap seimbang. Seimbang yang dimaksudkan disini adalah seimbang dalam hal pengambilan keputusan, bagaimana memperlakukan orang lain dengan sama, dan lain sebagainya. Sikap adil perlu dikembangkan dalam kehidupan bermasyarakat. Sikap adil akan menumpas kecemburuan sosial. Orang-orang yang mampu bersikap adil tentunya akan mendapatkan respon positif dari orang lain. Keadilan yang dilakukan seseorang hendaknya dilandasi dengan hati nurani yang baik. Jangan sampai berlaku adil hanya karena ada sesuatu di baliknya. Dengan berlaku adil kepada orang lain, maka tidak akan muncul pertentangan atau istilah 
pilih kasih. Seperti halnya kisah Nabi Yusuf saat beliau dipercaya menjadi raja di Mesir. Nabi Yusuf memperlakukan rakyatnya dengan adil, tidak ada diskrimininasi dalam kepemimpinan beliau. Membiasakan sikap adil dalam kehidupan sehari-hari akan membina jiwa kepemimpinan yang baik agar bijak bersikap ketika menghadapi orang dengan karakter yang berbeda-beda. Tegaknya keadilan akan melahirkan sebuah tatanan masyarakat yang harmonis (Rangkuti, 2017:2). Cakupan keadilan sangatlah luas. Keadilan dapat diterapkan dalam setiap sendi kehidupan. Rangkuti (2017:10) menyebutkan beberapa bidang yang dapat menerapkan keadilan dalam kehidupan sehari-hari, diantaranya yaitu bidang agama, hukum, politik, ekonomi, kesehatan, maupun pendidikan.

\section{Relevansi Tokoh Yusuf dengan Karakter Pemimpin Demokratis}

Pemimpin merupakan seseorang yang dipercaya untuk memimpin dan mengatur rencana kerja agar tujuan suatu instansi atau organisasi dapat tercapai. Keberadaan pemimpin dibutuhkan dalam komunitas, organisasi, atau instansi tertentu sebagai kepala pimpinan yang bertugas untuk memimpin rapat, bertanggung jawab terhadap apa yang dipimpinnya, serta memutuskan suatu keputusan. Pendapat ini didukung oleh Mutammimutsani (2020:541) yang menyatakan bahwa pemimpin merupakan seseorang yang memiliki tanggungjawab, mengatur rencana, mengatur strategi, serta mendorong anggotanya untuk bekerja. Pemimpin juga memiliki tugas untuk memutuskan suatu permasalahan atau menyetujui kesepakatan dalam sebuah forum.

Kepemimpinan seseorang memiliki karakteristik yang berbeda-beda. Setiap tipe kepemimpinan memiliki karakteristik sendiri-sendiri. Dari beberapa tipe kepemimpinan, model kepemimpinan yang akan dibahas dalam penelitian ini adalah kepemimpinan demokratis. Pemimpin demokratis merupakan pemimpin yang memiliki sikap terbuka dan senantiasa melibatkan bawahan/karyawan dalam proses pengambilan keputusan. Pemimpin demokratis senantiasa menerima masukan dari anggota-anggotanya untuk dijadikan pertimbangan pengambilan suatu keputusan (Mutammimutsani, 2002:541). Keberhasilan kepemimpinan seseorang dapat ditunjukkan melalui antusiasme karyawan dalam bekerja setiap hari. Apabila seorang pemimpin memiliki karakter demokratis yang kuat, maka keterlibatan antara pemimpin dan karyawan akan selalu terjaga. Hal inilah yang memicu tumbuhnya chemistry dalam bekerja. Dengan adanya chemistry yang kuat, maka kerjasama akan terjalin dengan mudah.

Karakter kepemimpinan demokratis perlu ditanamkan sejak dini agar karakter tersebut mampu terinternalisasi dalam diri setiap individu. Hal ini bertujuan untuk membekali generasi sekarang agar memiliki karakter yang baik dan berakhlak mulia. Melalui penelitian ini, akan diuraikan bagaimana relevansi karakter tokoh Yusuf dengan karakter pemimpin demokratis. Tokoh Yusuf dapat dijadikan sebagai teladan bagi individu jaman sekarang. Relevansi meneladani karakter Yusuf dalam pembentukan karakter pemimpin demokratis antara lain:

\section{Memberantas Munculnya Kasus Kriminalitas yang Dilakukan oleh Pemimpin}

Kasus kriminalitas yang terjadi di negeri ini semakin merajalela. Kriminalitas tidak hanya dilakukan oleh masyarakat biasa. Tetapi pada kenyataannya, kasus kriminalitas juga menjerat para pemimpin negara, meskipun tidak semuanya demikian. Kriminalitas bersifat relatif yang bergantung pada ruang, waktu, dan siapa yang menanamkan kejahatan itu (Rohman, 2016:128). Kasus yang menjerat para pemimpin negara biasanya berupa kasus korupsi, kekerasan terhadap mitra kerja, dan kesewenang-wenangan pemimpin. Terjadinya perbuatan semacam itu didasari oleh karakter pemimpin yang tidak demokratis. Sebagai contoh misalnya ada pemimpin yang terjerat kasus korupsi. Korupsi merupakan bentuk penyelewengan terhadap hak milik orang lain yang digunakan untuk kepentingan pribadi tanpa izin pemiliknya. Korupsi juga dapat diartikan sebagai perbuatan buruk yang dilakukan oleh seseorang dengan cara menyogok, menyuap, menerima sesuatu yang bertentangan dengan hukim dan merugikan uang negara. Korupsi yang banyak dilakukan berupa korupsi uang. 
Kasus kriminalitas seperti korupsi sebenarnya sudah mendapatkan penanganan dari KPK (Komisi Pemberantasan Korupsi). KPK sudah memberikan hukuman yang setimpal kepada oknum-oknum tekdakwa kasus korupsi. Upaya yang dilakukan oleh KPK tersebut merupakan upaya pasca kejadian (tindakan represif). Meskipun orang-orang di negeri ini mengetahui bahwasanya kasus pidana korupsi ini mendapatkan hukuman yang berat, namun hal tersebut tidak menimbulkan efek jera bagi koruptor. Kian hari pelaku korupsi makin bertambah. Untuk menumpas munculnya kasus kriminalitas semacam itu hendaknya diupayakan pencegahan (tindakan preventif). Dengan adanya pencegahan, maka kemunculan kasus pidana korupsi dapat ditekan. Pencegahan dapat diawali dengan cara membentuk karakter generasi saat ini agar berperilaku sesuai dengan karakter pemimpin demokratis.

Munculnya pelaku kriminalitas seperti halnya koruptor dikarenakan orang tersebut tidak memiliki kejujuran. Dalam melakukan pekerjaannya dilandasi oleh ketidakjujuran. Ketidakjujuran merupakan dasar utama melakukan korupsi. Hilmy (2013:7) menyatakan bahwa korupsi menyapu siapa saja yang ada di depannya. Korupsi juga dapat menyapu orang-orang saleh dari partai-partai suci yang selama ini diketahui menjadi benteng pemberantasan korupsi. Selain dipicu karena sikap ketidakjujuran, korupsi juga dapat disebabkan karena pemimpin tersebut tidak patuh terhadap agama. Apabila pemimpin negeri ini seluruhnya taat beragama, pastilah mereka akan takut untuk melakukan tindak pidana korupsi. Sebab pada dasarnya korupsi merupakan perbuatan tercela yang merampas hak milik orang lain. Hal tersebut dilarang dalam agama. Kurangnya ketaatan beragama bagi seorang pemimpin juga menjadi salah faktor pemicu adanya tindak pidana korupsi.

Keteladanan yang didapat dari tokoh Yusuf apabila mampu meneladani sikap jujur dan taat beragama adalah memberantas potensi kriminalitas yang dilakukan oleh pemimpin. Pembinaan karakter seorang pemimpin sangat dibutuhkan dalam rangka mencetak pemimpin-pemimpin bangsa yang berkarakter dan berakhlak mulia. Pada dasarnya, segala bentuk kajahatan didasari dengan adanya ketidakjujuran atau tidak transparan. Hal inilah yang perlahan-ahan harus disingkirkan dalam budaya kepemimpinan bangsa ini. Menemukan pemimpin yang jujur seperti halnya mencari jarum di antara tumpukan jerami, yang artinya sangat sulit ditemukan.

\section{Memunculkan Sosok Pemimpin yang Amanah}

Setiap orang pasti mengingkan sosok pemimpin yang amanah. Pemimpin yang amanah adalah pemimpin yang memiliki sikap terbuka, transparan, dan terdapat sinkronisasi antara perkataan dengan perbuatannya. Amanah dapat diartikan sebagai perbuatan yang dapat dipercaya oleh orang lain. Dengan kata lain, pemimpin yang amanah adalah pemimpin yang mampu dipercaya oleh orang yang dipimpinnya dan tidak mengecewakan orang-orang tersebut. Pemimpin yang amanah tidak akan menodai kepercayaan besar atas orang-orang yang dipimpinnya.

Amanah berkaitan dengan kepercayaan. Pemimpin yang amanah pastinya akan melakukan upaya terbaik untuk mencapai tujuan kepemimpinan. Hal itu disebabkan karena mereka sadar bahwasanya terdapat kepercayaan orang-orang yang dititipkan kepada beliau. Sehingga pemimpin yang amanah pantang untuk menghancurkan kepercayaan tersebut. Sikap amanah/dapat dipercaya dapat dibina dalam kehidupan sehari-hari. Salah satu caranya adalah dengan meneladani sosok Nabi Yusuf. Nabi Yusuf merupakan seorang raja di Mesir yang mampu berperilaku amanah. Sebagai seorang raja, Nabi Yusuf tidak hanya memberikan janji-janji manis kepada rakyatnya, tetapi beliau juga mampu mewujudkan janji tersebut. Hal itulah yang menyebabkan Nabi Yusuf menjadi raja yang dipercaya oleh rakyat Mesir.

Di masa sekarang ini, sosok pemimpin yang amanah sangat dibutuhkan. Sikap amanah menjadi modal keberlangsungan seorang pemimpin. Pemimpin yang amanah akan memiliki citra yang baik di mata rakyatnya, sehingga rakyat menaruh harapan besar terhadap pemimpin tersebut. Dengan mendapatkan tanggapan positif dari masyarakat, maka roda kepemimpinan akan berjalan secara seimbang tanpa terjadi kepincangan. Sebab pada dasarnya kepemimpinan yang baik adalah kepemimpinan yang melibatkan partisipasi aktif warga masyarakat. 


\section{Memunculkan Pemimpin yang Adil dan Bijaksana}

Salah satu indikator pemimpin demokratis adalah pemimpin yang mampu bersikap adil dan bijaksana. Adil dan bijaksana merupakan dua hal yang saling beriringan. Dengan adanya kebijaksanaan yang baik dalam kepemimpinan, maka keadilan akan terwujud. Demikian halnya dalam kisah Nabi Yusuf yang mana beliau digambarkan sebagai sosok pemimpin Mesir yang adil dan bijaksana. Dalam masa kepemimpinannya, Nabi Yusuf tidak memperlakukan rakyatnya dengan cara yang berbeda-beda. Rakyat Mesir diperlakukan dengan cara yang sama, baik bagi kaum konglomerat maupun rakyat biasa. Pada masa kepemimpinan Nabi Yusuf, keadilan benarbenar ditegakkan. Nabi Yusf juga berhasil menata agama di Mesir agar tidak terjadi perpecahan antar umat beragama. Sebagai seorang raja, Nabi Yusuf juga bersikap bijaksana dalam memutuskan suatu hal. Hal ini dapat dibuktikan dari proses pengambilan keputusan Nabi Yusuf. Sebagai contoh, Nabi Yusuf tidak merasa dendam atas perbuatan saudaranya yang dahulu telah mencelakainya, bahkan berniat ingin membunuhnya. Saat semua rakyat Mesir meminta bantuan sembako kepada Nabi Yusuf disaat kekeringan, Nabi Yusuf siap memberikan bantuan kepada siapa saja. Termasuk bagi keluarganya. Nabi Yusuf sudah menghapus rasa sakit hati dan memaafkan kesalahan saudara-saudaranya. Atas dasar itulah, Nabi Yusuf dapat dijadikan panutan seorang pemimpin yang bijaksana.

Pembinaan karakter adil dan bijaksana sangat penting di masa sekarang ini. Sebab sekarang ini banyak diketahui kasus-kasus pemimpin yang tidak adil serta hanya membela salah satu oknum atau dapat dikatakan pilih kasih. Karakter pemimpin demokratis tidaklah demikian. Pemimpin demokratis merupakan sosok pemimpin yang berlaku adil dan bijaksana kepada semua rakyatnya tanpa memandang siapa rakyat tersebut. Tidak ada perbedaan perlakuan kepada rakyat. Kepribadian tokoh Yusuf relevan dijadikan sebagai suri tauladan bagaimana karakter pemimpin demokratis. Dengan meneladani sikap-sikap Nabi Yusuf, maka karakter pemimpin demokratis dapat dikenalkan kepada generasi sekarang.

\section{SIMPULAN}

Relevansi tokoh Yusuf dengan karakter pemimpin demokratis didapatkan melalui proses keteladanan terhadap karakter yang dimiliki oleh Nabi Yusuf. Nabi Yusuf merupakan sosok lakilaki yang memiliki karakter jujur, taat beragama, sabar, teguh, rela berkorban, pemaaf, berserah diri, dan adil. Sifat-sifat yang dimiliki oleh Nabi Yusuf tersebut selaras dengan karakter yang harus dimiliki oleh pemimpin demokratis. Berdasarkan pemaparan tersebut, hal-hal yang harus dilakukan pemimpin untuk menjadi seorang pemimpin yang demokratis adalah menjadi sosok pemimpin yang amanah, adil dan bijaksana, serta tidak melakukan tindakan kriminal sebagai seorang pemimpin, seperti halnya korupsi. Karakter-karakter dari Nabi Yusuf tersebut perlu dicontoh dan dijadikan teladan bagi masyarakat, khususnya para pemimpin dalam menjalankan tugas dan kewajibannya. Penelitian ini terbatas pada relevansi karakter-karakter Nabi Yusuf dengan karakter pemimpin. Masih perlu penelitian tahap lanjutan untuk menguraikan nilai-nilai karakter yang terdapat dalam naskah ini dengan perspektif yang lebih luas.

\section{DAFTAR PUSTAKA}

Adi, H. (2019). Pengaruh gaya kepemimpinan demokratis dan otoriter terhadap kinerja karyawan di Hotel Gallery Prawirotaman Yogyakarta. (Skripsi, Sekolah Tinggi AMPTA Yogyakarta).

Al-Ghazali. (2013). Minhajul abidin: Jalan para ahli ibadah (Terjemahan minhajul abidin; Penerjemah: Abu hamas as-sasaky). Jakarta: Khatulistiwa Press.

Amin, M. (2017). Peran guru dalam menanamkan nilai kejujuran pada lembaga pendidikan. Jurnal Studi Manajemen Pendidikan, 1(1), 107-124. Diunduh dari: http://journal.iaincurup.ac.id/index.php/JSMPI/article/view/222. 
Anwar, K. (2020). Pembinaan sikap sosial dan taat beragama pada anggota karang taruna di Dusun Tumbu Desa Purwodadi Kecamatan Tegalrejo Kabupaten Magelang tahun 2020. (Skripsi, IAIN Salatiga).

Bungin, B. (2011). Penelitian kualitatif komunikasi, ekonomi, kebijakan publik, dan ilmu sosial lainnya. Jakarta: Prenada Media Group.

Daradjat, Z. (1970). Ilmu jiwa agama. Jakarta: Bulan Bintang.

Faruk. (2009). Pengantar sosiologi sastra: dari strukturalisme genetik sampai post-modernisme. Jakarta: Pustaka Pelajar.

Fathurrahman, O. (2015). Filologi Indonesia: Teori dan metode. Jakarta: Kencana Prenadamedia Goup.

Goldmann, L. (1981). Method in the sociology of literature. Terj. William Boelhower. Oxford: Basil Blackwell.

Hamka. (2013). Tasawuf modern. Jakarta: Pustaka Panjimas.

Hilmy, M. (2013, 1 November). Memutus mata rantai korupsi. Kompas, 1.

Mutammimutsani, Faiz, A., \& Hikma, A.N. (2020). Kepemimpinan demokratis: Pemimpin tua dan pegawai muda. Journal of Education, Psychology, and Counseling, 2(1), 541. Diunduh dari: https://ummaspul.e-journal.id/Edupsycouns/article/view/527.

Rangkuti, A. (2017). Konsep keadilan dalam perspektif Islam. Tazkiya, Jurnal Pendidikan Islam, $6(1), 1-10$.

Ratna, N.K. (2012). Penelitian sastra: Teori, metode, dan teknik penelitian sastra. Yogyakarta: Pustaka Pelajar.

Rohman, A. (2016). Upaya menekan angka kriminalitas dalam meretas kejahatan yang terjadi pada masyarakat. Jurnal Perspektif, 11(2), 125-134. Diunduh dari: http://jurnalperspektif.org/index.php/perspektif/article/download/187/533.

Samani, M. (2013). Pendidikan karakter: Konsep dan model. Bandung: Remaja Rosda Karya.

Sugiyono. (2013). Memahami penelitian kualitatif. Bandung: Alfabeta.

Wahyuningtyas, S. (2017).Unsur profetik dalam kumpulan cerpen Rusmi Ingin Pulang karya Ahmad Tohari. Jurnal PIBSI, 39(7), 1055. Diunduh dari: http://eprints.undip.ac.id/59010. 